551.4

\author{
- гоцьк \\ ьвівський н ціон льний університет імені в н \\ вул. . орошенк, 41, м. ввів, 79000, кр їн
}

исвітлено історичні спекти вивчення нтропогенних процесів не лише в меж х н шої кр їни, й з кордоном. ростежено перші спроби кл сифік ції з конкретно визн ченою озн кою. лючові слов : рельєф, рельєфотвірні процеси, нтропогенний вплив.

ьогодні геоморфологічн діяльність людини втілен в т ких м сшт 6 х, що м йже всі т м йже повсюди н емлі суч сні рельєфотвірні процеси, особливо екзогенні, т к чи ін кше пов'яз ні з діяльністю людини. кщо в 60-ті роки з зн ч ли, що людин н йефективніший зовнішній геоморфологічний чинник в економічно розвинених кр ïн $\mathrm{x}$, то нині ст ло очевидним, що проблем зміни поверхні літосфери діяльністю людини перетворюється н глоб льну.

ет і з вд ння ст тті поляг ють у дослідженні особливостей нтропогенної тр нсформ ції рельєфу рівнинних територій, с ме:

$>$ здійснення н лізу існуючих теоретико-методологічних н пр цюв нь із пит ння, яке розгляд ється;

$>$ вивчення н слідкових природно- нтропогенних процесів;

$>$ проведення типіз ції т кл сифік ції рельєфотвірних процесів і відкл дів.

ро вплив людини н природу з г лом і рельєф зокрем пис ли вже з XVII ст., проте до поч тку ХX ст. дослідження у цьому н прямі з кінчув лися лише конст тув нням ф кту впливу ( ільков, 1973).

слідки втруч ння людини у розвиток природних геоморфологічних процесів поч ли вивч ти з другої половини ст. досліджув ли грунтову ерозію, як виникл вн слідок інтенсивного освоєння європейцями івнічно мерик нського континенту. осії з цими проблем ми пов'яз ні пр ці . . окуч єв , . . озменко т ін..

н шій кр їні поч тком нтропогенного н пряму досліджень вв ж ють пр ці . . ерсм н . 1934 р. всю сукупність хімічних і технічних процесів, які спричинює людин, він визн чив поняттям техногенез.

ехносфер - це ч стин біосфери, перетворен людьми 3 допомогою прямого т непрямого впливу технічних з собів ( . . олодкін, 1987).

50-ті роки ст. вже був чіткий поділ усіх процесів н природні, природнонтропогенні т нтропогенні. роблем нтропогенного морфогенезу ст в л дед лі гострішою. нтропогенний чинник пост в головним у визн ченні інтенсивності т н пряму всіх екзогенних процесів. ого вплив н рельєфоутворення відбув ється н фоні з г льного впливу н всі елементи л ндш фту. розвитку нтропогенних процесів виявлено з г льні з кономірності:

(C) гоцьК ., 2010 
1) вони, як і всі екзогенні процеси, крім звітрюв ння, виконують три види роботи: руйнув ння, перенесення т н копичення продуктів руйнув ння;

2) нтропогенні процеси зон льні. будь-яких природних умов х людин може змінюв ти обриси земної поверхні т к, як їй потрібно, ле утворені при цьому форми рельєфу будуть розвив тися н д лі з зон льним типом;

3) нтропогенні процеси, регл ментов ні місцем прояву, ч сом, формою і розмір ми - керов ні.

оловними умов ми розвитку нтропогенних рельєфотвірних процесів $€$ т кі ( ipсенков , 1987):

$\checkmark$ пл нув ння соці льно-економічного розвитку того чи іншого регіону. йбільше зн чення при цьому м ють ті пл нув льні з ходи, які призведуть до прямих порушень цілісності земної поверхні (створення к н лів, к р'єрів, виїмок доріг), до помітних змін iii морфології (терикони, н сипи, д мби);

$\checkmark$ геолого-геоморфологічні, с ме - скл д гірських порід, н прям т інтенсивність суч сних тектонічних рухів літосфери;

$\checkmark$ метеорологічні умови, передусім вітровий режим, х р ктер тмосферних оп дів;

$\checkmark$ ст н грунтово-рослинного покриву;

$\checkmark$ н йпоширеніші види нтропогенного впливу н рельєф (землеустрій, будівництво, розробк покл дів корисних коп лин).

60-70-ті роки ст. конст тов но небув ле зрост ння можливостей людини у перетворенні природи. огляду н це з'явил ся зн чн кількість робіт, присвячених вирішенню вл сне проблем впливу людини н рельєф в окремих регіон х з лежно від типу діяльності: вплив діяльності людини н території міст ( отлов, 1977, 1978), вплив виробничо-технічної діяльності н процеси рельєфоутворення ( збукін , едоров, 1975).

ротягом цього періоду були спроби виявити різном нітність форм нтропогенного генезису т їхній зв'язок з природними процес ми.

. . ер симов (1967), розвив ючи ідеї про дві групи нтропогенних процесів

. йєля i . рш , розрізнив дв н прями діяльності людини. одного боку людин безпосередньо згл джує нерівності рельєфу, тобто є гентом денуд ції; з іншого втруч ється в діяльність природних екзогенних процесів. підсумку утворюються різном нітні типи культурного геоморфологічного л ндш фту: сільськогоспод рський, іриг ційний, гірничо-промисловий т оборонний.

комплексі рельєфотвірних чинників в жливу роль відігр ють екзогеодин мічні процеси т явищ . юдин в одних вип дк х підсилює, в інших - зменшує їхній вплив. . . отлов (1978) розрізнив три к тегорії екзогенних рельєфотвірних процесів т явищ з ступенем впливу людини н їхне формув ння:

1) природні рельєфотвірні процеси т явищ , які не з зн ють впливу діяльності людини (екзогенні процеси, яких не торкнул сь техносфер );

2) природно- нтропогенні рельєфотвірні процеси т явищ, кількісно т якісно змінені діяльністю людини ( бр зія, ерозія, селі, к рст т ін.);

3) нтропогенні рельєфотвірні процеси т явищ, виникнення т розвиток яких повністю спричинене діяльністю людини (переробк берегів водосховищ, пров ли, суфозія).

одо вивчення х р ктеру прямого перетворення рельєфу чи стимуляції т кого перетворення певними груп ми екзогенних процесів рельєфоутворення дослідники вже д вно роблять спроби розробити певні кл сифік ції. ьогодні кл сифік ції форм рель- 
єфу, зумовлених діяльністю людини, вибудов ні н різних критеріях, кожен з яких, очевидно, обр ний для вирішення певної проблеми ( ільков, 1974).

. . отлов (1978) виділив т кі типи впливу н рельєф:

- прямі т непрямі;

- цілеспрямов ні, стихійні т резон нсні;

- місцеві, лок льні, регіон льні т глоб льні;

- короткотермінові, трив лі т вікові.

еред нтропогенних геологічних рельєфотвірних процесів т явищ розрізняються т кі кл си:

- н нтропогенний літогенез;

- процеси т явищ, зумовлені зміною термічного режиму порід т підземних вод, обводненості т вологості порід, н пруженого ст ну порід у м сиві.

рямий вплив н рельєф передб ч є штучне зниження т підвищення відміток поверхні землі. епрямий вплив пов'яз ний з природно- нтропогенними т нтропогенними геологічними рельєфотвірними процес ми т явищ ми.

. . олодкін (1987), дослідивши пр цю рік р ун “ юдин змінює форму (поверхні) емлі” (1970), простежив у ній три основних типи рельєфотвірної діяльності людини:

безпосереднього т цілеспрямов ного впливу н рельєф, н прикл д, створення н сипів, тер сов них схилів т ін.;

безпосереднього, ле нецілеспрямов ного, пов'яз ного зі зміною рельєфу у місцях розробки корисних коп лин, будівництв доріг;

опосередков ного, яке виявляється у зміні природних геоморфологічних процесів.

. . вонков (1959) розрізнил прямий вплив людини н рельєф (будівництво к н лів) і непрямий, який виявляється у зміні деяких екзогенних процесів, н прикл д, ктивіз ції площинного змиву т дефляції під ч с обробітку полів.

. . олодкін (1987) розробив кл сифік цію рельєфоутворюючих процесів, пов'яз них із діяльністю людини, т кож н вів їхні н слідкові процеси т явищ (див. т блиця).

. . отлов (1978) усі нтропогенні процеси, які стосуються безпосередньо змін рельєфу, розділив н дві групи. о першої з числено ті процеси, які зумовлюють зниження рівня поверхні землі, с ме:

- зріз ння підвищень, уступів, виположення, тер сув ння схилів у зв'язку з вертик льним пл нув нням місцевості, будівництвом і бл гоустроєм;

- вл штув ння довготрив лих виїмок (к р'єрів, дорожніх прорізів, ровів, тр ншей, к н лів т ін.);

- штучне розширення русел рік;

- просід ння лесових т інших порід ун слідок з мочув ння;

- н нропогенний к рст з утворенням к рстового рельєфу;

- н нтропогенн суфозія з осід нням поверхні землі т утворенням лійок і пров лів;

- осід ння поверхні землі, спричинене видобув нням н фти т г зу;

- осід ння поверхні землі під впливом дин мічних н в нт жень;

- денуд ція рельєфу, зумовлен переробкою берегів водосховищ, к н лів, т кож нтропогенною площинною т лінійною ерозією; 
- денуд ція рельєфу, зумовлен нтропогенними зсув ми, обв л ми, селями; ктивіз цією природних екзогеодин мічних рельєфотвірних процесів т явищ ун слідок діяльності людини.

л сифік ція нтропогенних рельєфоутворюючих процесів

\begin{tabular}{|c|c|c|}
\hline \multirow{2}{*}{ ид діяльності людини } & \multicolumn{2}{|c|}{ роцеси т явищ } \\
\hline & нтропогенні & пост нтропогенні \\
\hline 1 & 2 & 3 \\
\hline $\begin{array}{c}\text { емлеустрій } \\
\text { рриг ція }\end{array}$ & $\begin{array}{l}\text { творення штучних } \\
\text { водойм } \\
\text { л нув ння поверхні зем- } \\
\text { лі під зрошення } \\
\text { творення поверхонь з } \\
\text { техногенним мікро- } \\
\text { рельєфом } \\
\text { ер ціон льне викорис- } \\
\text { т ння зрошув льних вод } \\
\text { озорюв ння вздовж } \\
\text { схилів } \\
\text { ер сув ння схилів - ство- } \\
\text { рення ступеневого нтро- } \\
\text { погенного рельєфу }\end{array}$ & $\begin{array}{l}\text { ереробк берегів т дн } \\
\text { водосховищ } \\
\text { мін режиму поверхневого стоку } \\
\text { води } \\
\text { онцентр ція поверхневого стоку } \\
\text { вздовж д мб к н лів і н тимч со- } \\
\text { вих зрошув ч х, денуд ція д мб і } \\
\text { схилів к н лів } \\
\text { ідвищення рівня грунтових вод, } \\
\text { вторинне з солення т з боло- } \\
\text { чення грунтів } \\
\text { ришвидшен ерозія грунтів, } \\
\text { ктивіз ція з мулення водоймищ } \\
\text { т рік } \\
\text { г с ння денуд ції н схил х }\end{array}$ \\
\hline $\begin{array}{l}\text { идобуток корисних } \\
\text { коп лин } \\
\text { м'яного вугілля } \\
\text { удівельних м тері лів }\end{array}$ & $\begin{array}{l}\text { ідземні порожнини т } \\
\text { утворення териконів } \\
\text { творення к р'єрів, коп - } \\
\text { лень т інших відкритих } \\
\text { розробок }\end{array}$ & $\begin{array}{l}\text { росід ння поверхні н д підзем- } \\
\text { ними порожнин ми, пров ли, нт- } \\
\text { ропогенний к рст, дефляція по- } \\
\text { верхні териконів, змін тектоніч- } \\
\text { ного режиму території } \\
\text { р віт ційні процеси (обв ли, } \\
\text { осипи т ін.) н розроблених схи- } \\
\text { л х к р'єрів, розвиток лінійних } \\
\text { форм розмиву н місці деяких ко- } \\
\text { п лень, створених н схил х до- } \\
\text { лин рік т б лок }\end{array}$ \\
\hline $\begin{array}{l}\text { удівництво } \\
\text { іст т інших н селених } \\
\text { пунктів }\end{array}$ & \begin{tabular}{lr} 
& \\
\multicolumn{1}{l}{ порудження } \\
підземного тіського \\
$\begin{array}{l}\text { господ рств } \\
\text { н земного }\end{array}$
\end{tabular} & $\begin{array}{l}\text { ормув ння нтропогенних } \\
\text { відкл дів (т к зв ного } \\
\text { культурного ш ру), підвищення } \\
\text { рівня грунтових вод т } \\
\text { посл блення водно-ерозійних } \\
\text { процесів } \\
\text { сід ння поверхні міст під впли- } \\
\text { вом ст тичного н в нт ження н } \\
\text { грунти, дин мічного (від впливу }\end{array}$ \\
\hline
\end{tabular}


кінчення т бл.

\begin{tabular}{|c|c|c|}
\hline 1 & 2 & 3 \\
\hline opiг & $\begin{array}{l}\text { ідготовк поверхні землі } \\
\text { для тр сув ння доріг, } \\
\text { створення н сипів } \\
\\
\text { удівництво д мб у долині } \\
\text { ріки }\end{array}$ & $\begin{array}{l}\text { різном нітних мех нізмів і м - } \\
\text { шин) т ін. } \\
\text { еформ ція грунтів під н в нт - } \\
\text { женням тр нспорту, концентр ція } \\
\text { поверхневих вод уздовж доріг, } \\
\text { розмив нез кріплених схилів до- } \\
\text { рожніх н сипів, утворення н міс- } \\
\text { ці деяких грунтових доріг виїмок } \\
\text { мін х р ктеру водної ерозії т } \\
\text { кумуляції в руслі й н з пл ві } \\
\text { вн слідок зміни гідрологічного } \\
\text { режиму ріки }\end{array}$ \\
\hline ісомеліор ція & $\begin{array}{l}\text { роведення полез хисних } \\
\text { ярково-б лкових } \\
\text { лісон с джень }\end{array}$ & $\begin{array}{l}\text { ниження ктивності водно-ерозі- } \\
\text { йних процесів і пилових бур, збіль- } \\
\text { шення вологи в грунт х і збіль- } \\
\text { шення протиерозійної стійкості }\end{array}$ \\
\hline
\end{tabular}

руг груп нтропогенних процесів зумовлює підвищення рівня поверхні землі. о неї н леж ть:

- штучне цілеспрямов не підвищення рівня у зв'язку з будівництвом і господ рським освоєнням території (н сипи);

- н гром дження грунтових відв лів з підземних т поверхневих розробок (терикони, грунтові зв лищ, пульпосховищ );

- н гром дження промислових, будівельних т господ рських відходів;

- зведення довготрив лих земляних споруд (кург ни, д мби, в ли, дорожні н сипи т ін.);

- стихійне н копичення суб ер льних нтропогенних відкл дів (культурні ш ри);

- н бух ння глинистих порід ун слідок штучного зволоження т ін.

ост нні роки різко поч л збільшув тися кількість публік цій щодо проблем, які торк ються пит нь перетворення поверхні літосфери геоморфологічною діяльністю людини. , незв ж ючи н зн чну з цік вленість геоморфологічними спект ми діяльності людини, проблем й н д лі не вирішен . едост тньо досліджене т кож пит ння порушення рівнов ги в земній корі вн слідок діяльності людини, хоч н порушення природних зв'язків зверт ли ув гу неоднор зово, у тому числі й . . ер сімов, який розгляд в діяльність людини з погляду співвідношення діяльності ендогенних т екзогенних сил ун слідок “виведення з рівнов ги” с морегулюв льного мех нізму.

іяльність людини зн чно тр нсформує рельєф як вертик льно, т к і площинно. н ліз впливу людини д $є$ підст ви вв ж ти їі н йв жливішим чинником нтропогенного перетворення форми емлі, ктивним тр нсформ тором природного рельєфу ( олтун ., 2005).

продовж нтропогенної еволюції можн виділити т кі з кономірності:

) 3 г льне нівелюв ння рельєфу, зменшення різниці висот;

б) поступове зникнення природного мікрорельєфу;

в) стир ння геоморфологічних гр ней н поверхні землі (уступів, тер с т ін.);

г) розвиток від'ємних і дод тних форм мікрорельєфу; 
д) процес підвищення рівня поверхні перев ж є н д процесом зниження перев жно з вдяки добув нню з н др н поверхню землі величезних м с порід т н копичення відходів виробництв т побуту.

нтропогенні зміни рельєфу вплив ють н розвиток 6 г тьох вз ємопов'яз них екзогеодин мічних процесів т явищ. ільшість із перелічених вище нтропогенних рельєфоперетворюв льних процесів т явищ м ють зн чне регіон льне поширення. ід ч с н лізув ння суч сних неотектонічних рухів дуже в жливо розрізняти нтропогенні зміни рельєфу, особливо підняття т опуск ння поверхні землі, зумовлені нтропогенними геологічними процес ми т явищ ми, від природних.

1. збукін . ., едоров . метод х к ртиров ния техногенного рельеф // роблеми геоморфологического к ртиров ния. ез. докл. .: , $1975 . \quad$. 44-45.

2. ер симов . . реобр зов ние природы и р звитие геогр фической н уки в . ( черки по конструктивной геогр фии). $\quad . \quad$ н ние, 1967.96 с.

3. вонков . . зучение рельеф в пр ктических целях. $\quad . \quad$ еогр фгиз, 1959. 304 с.

4. олтун . н ліз кл сифік цій нтропогенного рельєфу // ук. 3 п. ерноп. пед. ун-ту. ер. геогр. 2005. ип. 1(7). . 15-19.

5. отлов . . зменение геоморфологической среди под влиянием деятельности человек . .: едр , 1978. 263 с.

6. ильков . . нтропогенн я геоморфология // учные 3 писки оронежского отдел еогр ф. о-в . оронеж: зд-во оронеж. ун-т , 1974. . 7-9.

7. ильков . . еловек и л ндш фты. черки нтропогенного л ндш фтоведения. . . ысль, 1973. $224 \mathrm{c}$.

8. олодкин . . нтропогенный морфогенез степных р внин. остов н- .: зд-во остов. унт , 1987. $82 \mathrm{c}$.

9. олодкин . . нтропогенное рельефообр зов ние степных р внин ( прим. р внин 6 ссейн иж. он ). тв. ред. . . ойко; остов. ун-т. остов н- : зд-во остов. ун-т , 1992. $140 \mathrm{c}$.

10. ирсенков . . орфодин мик нтропогенного рельеф . . .

\section{ANALYSIS OF THE STATE OF STUDY AND CLASSIFICATIONS OF ANTHROPOGENIC PROCESSES}

\section{O. Lahotska}

Ivan Franko National University of Lviv, . Doroshenko St., 41, UA - 79000 Lviv, Ukraine

The historical aspects of study of anthropogenic processes are reflected not only within the limits of our country, but also abroad. The maiden attempts of classification are traced on a concretely certain sign.

Key words: relief, relief processes, anthropogenic influence. 


\author{
гоцк \\ ввовский н цион льный университет имени в н \\ ул. . орошенко, 41, г. ьвов, 79000, кр ин
}

свещены исторические спекты изучения нтропогенных процессов не только в предел х н шей стр ны, но и 3 рубежом. рослежены первые попытки кл ссифик ций по конкретно определенному призн ку.

лючевые слов : рельеф, рельефообр зующие процессы, нтропогенное влияние.

т ття н дійшл до редколегії 08.09.2009

рийнят до друку 20.09.2009 